\title{
Study on Marketing Efficiency of Rapeseed and Mustard crop in Jaipur district of Rajasthan, India
}

\author{
Mukesh Kumar Yadav ${ }^{1 *}$, Amod Sharma ${ }^{2}$, Ajay Kumar $^{3}$ and Rokoneituo Nakhro ${ }^{4}$
}

\author{
${ }^{1 *}$ Dept. of Agricultural Economics, SASRD, NU, Medziphema, Nagaland (797 106), India \\ ${ }^{3}$ Dept. of Ag Economics, CCS Haryana Agricultural University, Hisar, Haryana (125 004), India \\ ${ }^{2 \& 4}$ Dept. of Agricultural Economics, Nagaland University, Dimapur, Nagaland (797 112), India
}

\author{
Corresponding Author \\ Mukesh Kumar Yadav \\ e-mail: mukeshyadav101990@gmail.com
}

\author{
Article History \\ Article ID: IJEP0223 \\ Received in $26^{\text {th }}$ October, 2017 \\ Received in revised form 04 ${ }^{\text {th }}$ March, 2018 \\ Accepted in final form 02 ${ }^{\text {nd }}$ April, 2018
}

\begin{abstract}
Rajasthan, one of the major rapeseed and mustard producing states in India, predominantly cultivate Indian mustard (Brassica juncea L.). The present study conducted in Jaipur district of Rajasthan reveals that per hectare marketed surplus was found out to be highest (2212.50 q) on medium farms, followed by $1142.80 \mathrm{q}$ and $145.50 \mathrm{q}$ on small and marginal farm, as the marketed surplus was higher than marketable surplus for all size group of farmers. Two marketing channels were identified viz., channel I: Producer-Consumer and channel II: ProducerRetailer-Consumer. Pattern of disposal showed that channel II was the most effective for marginal, small and medium groups viz., they transacted $80.34,71.50$ and $77.25 \%$ of their marketed surplus through this channel. The cost incurred by intermediaries was $27.29 \%$ of the total marketing cost in channel II. Producer share in consumer rupees' was found higher on channel I (94.33 \%) due to the absence of intermediaries as compared to channel II (91.73\%).
\end{abstract}

Keywords: Channel, Jaipur, marketing, mustard, price-spread, rapeseed

\section{Introduction}

Indian mustard (Brassica juncea L.) is predominantly cultivated in the states of Rajasthan, Uttar Pradesh, Haryana, Madhya Pradesh and Gujarat; contributes $81.50 \%$ area and $85.50 \%$ production during the year 2010 to 2014, while during 20132014 more than $84.00 \%$ of the total rapeseed-mustard acreage and production in the country is accounted for by these states, out of which more than $45.0 \%$ contributed by Rajasthan state alone (SHR, 2015). The crop takes 135 to 150 days to mature. The cultivation of brown sarson, which once dominated the entire rapeseed-mustard growing region is now shadowed by Indian mustard. There are two different ecotypes of brown sarson (Brassica rapa var brown sarson): lotni (self-incompatible) and tora (self-compatible). The lotni is predominantly cultivated in colder regions of the country particularly in Kashmirand Himachal valley. Yellow sarson (Brassica rapa var. yellow sarson) is now mainly grown in Assam, Bihar, North-eastern States, Orissa, eastern Uttar Pradesh and West Bengal. The toria (Brassica rapa var. toria) on the other hand is cultivated in limited areas of eastern Uttar Pradesh. It is a short duration crop cultivated largely in Assam, Bihar, Orissa and West Bengal in the east mainly as winter crop. In Haryana, Himachal Pradesh, Madhya Pradesh, Punjab, Uttaranchal and western Uttar Pradesh (Dhakre and
Sharma, 2010), it is grown as a catch crop during SeptemberDecember. Taramira (Eruca sativa) is grown in the drier parts of North West India comprising the states of Rajasthan, Haryana and Uttar Pradesh (Banafar et al., 2006).

Rapeseed-mustard group of crops is the major oilseed crop of India. India holds a premier position in rapeseed-mustard economy of the world with 2 nd and 3rd rank in area and production, respectively (Das and Sharma, 2012). This group of oilseed crops is gaining wide acceptance among the farmers because of adaptability for both irrigated as well as rainfed areas and suitability for sole as well as mixed cropping (Sharma, 2018). Besides, it offers higher return with low cost of production and low water requirement. Being a major rabi (winter season) oilseed crop and having an advantage of soil moisture conserved during monsoon, it has greater potential to increase the availability of edible oil from the domestic production (Yadav et al., 2017).

Despite the high quality of oil and meal and also its wide adaptability for varied agro-climatic conditions, the area, production and yield of rapeseed-mustard in India have been fluctuating due to various biotic and abiotic stresses coupled with India's domestic price support programme. Nevertheless, the crop has potential to ensure the nutritional security and contribute to livelihood security (Choudhary et al., 2017). 


\section{Materials and Methods}

The research study was being undertaken during the year 2014-2015 in Jaipur district of Rajasthan. The study comprises of 75 Sample farmers by following a multi stage stratified random sampling technique. From Jaipur district, two blocks (Govinagarh and Shahpura) were selected purposively. A separate list of villages falling under the jurisdiction of both the selected blocks was prepared and two villages from Govindgarh and three villages from Shahpura block making a total of five villages were selected randomly. From each village, 15 farmers were selected randomly from the list making a sample size of 75 for the study. The selected farmers were stratified into three groups viz. Group 1 marginal (0.0 to 2.0 ha) Group-2 small (2.01 to 4.0) and group-3 medium (4.01 ha and above) respectively, based on the study area under land holding of respondents.

\subsection{Analytical tools}

\subsubsection{Marketing channels of Rapeseed and mustard}

The marketing channels of Rapeseed and mustard were identified based on the intermediaries or middleman involved from the point of production to the point of ultimate consumer similar studies were carried out by Meena and Singh (2012), Sharma (2012), Sharma (2013), Sharma (2018).

\subsubsection{Marketing cost, margins and price spreads}

Marketing cost was calculated by estimating the cost incurred in the process of marketing of Rapeseed and mustard. The cost incurred after harvesting of the crop till it reaches the final consumers hand generally constitutes the marketing cost. It includes transportation cost, handling cost, storage cost, market fees, weighing charges and labour charges for packing, loading and unloading. The marketing costs at various stages of Rapeseed-mustard marketing were calculated and finally the total cost was computed.

Absolute marketing margin of its intermediaries at any stage of marketing was calculated as follows: $\mathrm{MM}_{\mathrm{i}}=\mathrm{SP}_{\mathrm{i}}-\left(\mathrm{PP}_{\mathrm{i}}+\mathrm{MC}_{\mathrm{i}}\right)$ Whereas: $\mathrm{MM}_{\mathrm{i}}=$ Marketing margin of the $\mathrm{i}^{\text {th }}$ middlemen

$\mathrm{SP}_{\mathrm{i}}=$ Selling price of the $\mathrm{i}^{\text {th }}$ middlemen

$\mathrm{PP}_{\mathrm{i}}=$ Purchase price of the $\mathrm{i}^{\mathrm{ith}}$ middlemen

$M C_{i}=$ Marketing cost incurred by the $i^{\text {th }}$ middlemen

After the calculation of the marketing margins at different stages, finally the total marketing margins were calculated.

\subsection{Price spread}

Price spread is the difference between the price paid by the consumer and the price received by the producer. It may consist of marketing costs and margins. The price spread analysis was carried out as follows:

Producer'shareinconsumer'srupee $(\%)=100 \times($ Producer's Price) $\div$ (Consumer's Price)

Similarly, the share of the total marketing cost and the total marketing margins were also estimated to analyze the price spread.

\subsection{Marketing efficiency}

Marketing efficiency is essentially for the degree of market performance and the concept is so broad and dynamic. It is defined in ratio and an increase in ratio represents improved efficiency and a decrease denotes reduced efficiency. The efficiency of various identified marketing channels was calculated through the empirical assessment of marketing efficiency.

\subsubsection{Ratio of output to input (conventional method)}

$\mathrm{ME}=(\mathrm{O} \div \mathrm{I}) \times 100$

Whereas: $\mathrm{ME}=$ Index of marketing efficiency

$\mathrm{O}=$ Value added

$\mathrm{I}=$ Marketing cost

Value added - Difference of the price paid by the consumer to price received by the producers.

\subsubsection{Shepherds formula: $\mathrm{ME}=\mathrm{CP} \div \mathrm{MC}$}

Whereas: $M E=$ Index of marketing efficiency

$$
\begin{aligned}
& \mathrm{CP}=\text { Consumer's purchase price } \\
& \mathrm{MC}=\text { Total marketing cost. }
\end{aligned}
$$

Keeping in mind the limitation of the above model, Acharya has suggested a modified model of measurement MME can be calculated as:

\subsubsection{Acharya's Model}

$\mathrm{MME}=\mathrm{FP} \div(\mathrm{MC}+\mathrm{MM})$

Whereas: $\mathrm{MME}=$ Modified measure of index of marketing efficiency

$\mathrm{FP}=$ Price received by farmer

$\mathrm{MM}=$ Marketing margin

$\mathrm{MC}=$ Total marketing cost

\section{Results and Discussion}

\subsection{Marketing Channels for Rapeseed and Mustard growers}

Agricultural commodities are produced by various cultivators in their farms. But the produce is consumed by people throughout the country at various places. The path followed by these commodities till they reach to final consumer is known as marketing channels. The length of channels varies from commodity to commodity and also depends on the quantity to be moved, the nature and degree of specialization in production. In present study, two marketing channels of rapeseed and mustard crop growers in Jaipur district of Rajasthan are identified. Two channels are as follows:

a. CHANNEL I: Producer-Consumer.

b. CHANNEL II: Producer-Retailer-Consumer.

Table 1 reveals that the amount of quantity sold through the 


\begin{tabular}{lcccccccc}
\hline \multicolumn{7}{l}{ Table 1: Effectiveness of various marketing channels for rapeseed and mustard crop } \\
\hline \multicolumn{7}{l}{ Channels } & \multicolumn{7}{c}{ Marginal } & \multicolumn{2}{c}{ Small } & \multicolumn{1}{c}{ Medium } & \multicolumn{2}{c}{ Total } \\
\hline \multicolumn{1}{l}{ Qty (qtl) } & $\%$ & Qty (qtl) & $\%$ & Qty (qtl) & $\%$ & Qty (qtl) & $\%$ \\
I & 28.47 & 19.75 & 325.71 & 28.50 & 503.34 & 22.75 & 857.52 & 24.50 \\
II & 116.89 & 80.34 & 817.16 & 71.50 & 1709.12 & 77.25 & 2643.17 & 75.50 \\
Total & 145.50 & 100.00 & 1142.87 & 100.00 & 2212.5 & 100.00 & 3500.70 & 100.00 \\
\hline
\end{tabular}

(The figure in the parenthesis indicates percentage in total)

two channels as channelll was more effective channel through which marginal, small and medium farmers, transacted $80.34 \%, 71.51 \%$ and $77.25 \%$ of their marketed surplus respectively. $7.50 \%$ of the total marketed surplus was sold through this channel, while through channell, $24.50 \%$ of the total produce was sold. Most of the farmers choose to sell their produce through channel II, which may be due to lack of knowledge about the market price, small quantity of the produce and high cost of transportation, similar study were carried out by Banafar et al., (2006) in the mustard growing area of Chhattisgarh found that the marketing channel II (producer-processors of wholesale dealers of mustard oil and cake-Retailers of mustard oil and cake-consumer) to be most efficient marketing channel.

\subsection{Marketed and marketable surplus}

Marketable surplus refers to the residential quantity left with the producer after meeting his requirement for family consumption, farm needs, and payment in kind to casual and permanent labourers, the landlord, artisans and others. The quantity of the produce which can be made available to the non-farm population is simply known as marketed surplus. It is the actual amount of produce which producer sold out of their year's production irrespective of his requirements, family consumption, wastage and other payments. On the other hand, marketable surplus is that quantity of the produce which is left with the producer after meeting his consumption and farm need or requirements. It is the residual left with the producer after meeting his requirements for family consumption and other requirements such has seeds, feed and payment to labour and further post harvest management for value addition is mostly prevailing in the rapeseed and mustard crop in the study area.

Table 2 and Figure 1 reveals that the area, production, nonmarket transaction, marketable surplus and marketed surplus of rapeseed and mustard crop or growers. It reveals that the average size of operational land holding under rapeseed and mustard crop or growers is $0.91 \mathrm{ha}, 3.08 \mathrm{ha}, 6.39$ ha for marginal, small and medium respectively. The average yield hectare $^{-1}$ is highest on medium group of farmers, followed by small and marginal group of farmers with the yield hectare ${ }^{-1}$ of

\begin{tabular}{|c|c|c|c|c|c|c|c|c|}
\hline SI. No. & $\begin{array}{c}\text { Farm size } \\
\text { Group }\end{array}$ & $\begin{array}{l}\text { Area under } \\
\text { rapeseed and } \\
\text { mustard (ha) }\end{array}$ & $\begin{array}{l}\text { Production } \\
\text { (qt) }\end{array}$ & $\begin{array}{l}\text { Av. Area under } \\
\text { rapeseed and } \\
\text { mustard (ha) }\end{array}$ & $\begin{array}{l}\text { Per ha } \\
\text { Produc- } \\
\text { tion (qt) }\end{array}$ & $\begin{array}{l}\text { Requirement } \\
\text { for family con- } \\
\text { sumption + } \\
\text { seed+ oil cake }\end{array}$ & $\begin{array}{l}\text { Market- } \\
\text { able sur- } \\
\text { plus (qt) }\end{array}$ & $\begin{array}{l}\text { Marketed } \\
\text { surplus } \\
\text { (qt) }\end{array}$ \\
\hline 1 & Marginal & $16.38(5.96)$ & 171.20 & 0.91 & 10.45 & 29.40 & 141.80 & 145.50 \\
\hline 2 & Small & $98.52(35.87)$ & 1206.87 & 3.08 & 12.25 & 76.50 & 1130.37 & 1142.87 \\
\hline 3 & Medium & $159.75(58.17)$ & 2236.5 & 6.39 & 14.0 & 56.0 & 2180.5 & 2212.50 \\
\hline Total & & $274.65(100)$ & 3614.57 & 10.38 & 36.75 & 161.90 & 3452.67 & 3500.70 \\
\hline $\begin{array}{l}\text { A ver- } \\
\text { age }\end{array}$ & & 91.55 & 1204.85 & 3.46 & 12.25 & 53.97 & 1150.89 & 1166.9 \\
\hline
\end{tabular}

(The figure in the parenthesis indicates percentage to the total)

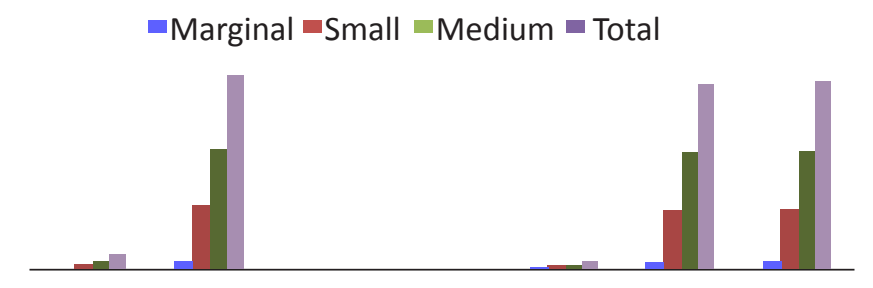

Figure 1: Marketable and marketed surplus of Rapeseed and Mustard growers
$1.45 q, 12.25 q$ and $14.00 q$ ha $^{-1}$ on medium, small and marginal farm size group, respectively. The marketed surplus is less than the marketable surplus, this may be due the price fluctuation, where the farmers are not will to sell the produce is very low price or the quantity is too small to take it to the market.

\subsection{Marketing cost, margin and price spread}

Marketing cost are the actual expenses incurred for bringing goods and services from the producer to consumer. The 
difference between the final price paid by the consumer for a commodity or a product and the price received by a grower of a crop or a primary producer may be taken, roughly to represent the costs of marketing of that commodity. Marketing costs would include handling charges at local points, assembling, transport and storage, financing, risk taking, market intelligence, and profit margin taken out by different agencies.

3.3.1. Marketing costs and margins of Rapeseed and Mustard crop or growers through channel-I

The Table 3 reveals that the marketing cost was observed INR 170.63 among the costs, transport cost was the most important with accounted INR 118.30 of total marketing cost. The next cost was the labour charge cost INR 34.00, followed by packaging cost INR 10.00, miscellaneous cost of INR. 8.33 of the total marketing cost, respectively. The producer's net share polled data was $94.33 \%$ in the consumer's price. The maximum producer's share in consumer price was $95.27 \%$ on marginal farm, followed by $94.16 \%$ on small farm and it was least $93.57 \%$ medium size groups, respectively.

Table 3: Costs and margin during the marketing of Channell (Producer-Consumer)

\begin{tabular}{|c|c|c|c|c|c|}
\hline \multirow{2}{*}{$\begin{array}{l}\text { SI. } \\
\text { No. }\end{array}$} & \multirow[t]{2}{*}{ Particulars } & \multicolumn{4}{|c|}{ Farm size groups } \\
\hline & & $\begin{array}{l}\text { Mar- } \\
\text { ginal }\end{array}$ & Small & $\begin{array}{l}\text { Me- } \\
\text { dium }\end{array}$ & Pooled \\
\hline 1. & $\begin{array}{l}\text { Producer's } \\
\text { sale price to } \\
\text { consumer }\end{array}$ & 3000.00 & 3015.00 & 3021.00 & 3012.00 \\
\hline 2. & $\begin{array}{l}\text { Cost in- } \\
\text { curred by } \\
\text { Producer: }\end{array}$ & & & & \\
\hline i. & Packing Cost & 8.00 & 10.00 & 12.00 & 10.00 \\
\hline li & $\begin{array}{l}\text { Transport } \\
\text { Cost }\end{array}$ & 110.00 & 120.00 & 125.00 & 118.33 \\
\hline lii & Market cost & 0.0 & 0.0 & 0.0 & 0.0 \\
\hline IV & Labour cost & 19.00 & 38.00 & 45.00 & 34.00 \\
\hline V & $\begin{array}{l}\text { Miscella- } \\
\text { neous cost }\end{array}$ & 5.00 & 8.00 & 12.00 & 8.33 \\
\hline & Total (i-v) & 142.00 & 176.00 & 194.00 & 170.63 \\
\hline 3. & $\begin{array}{l}\text { Producer's } \\
\text { net share } \\
\text { ((\%age) }\end{array}$ & 95.27 & 94.16 & 93.57 & 94.33 \\
\hline
\end{tabular}

\subsubsection{Marketing cost and margin in marketing of channelll}

Table 4 reveals that the overall farm on marketing cost of rapeseed and mustard crop was accounted $91.73 \%$ was of producer's share in consumer's price, out of which maximum amount was shared by retailers as their profit and share of their margin was $84.98 \%$, whereas, the producer share in consumer's rupee was the lowest in this channel because of high marketing cost and involvement of expenditures incurred. Study of disposal pattern is essential in order to get the clear picture of marketing pattern and therein influencing effect on the marketed surplus. The marketing cost (producers sold their produce through retailers to consumers), it was observed that the total cost was INR 189.35 among the cost, transportation cost was the most important which accounted INR 129.67, of total marketing cost. The next important cost was the labour cost INR 22.67, followed by miscellaneous cost INR 12.34, storing cost INR 11.34 and packing cost of INR 7.76 market charges INR 2.00 of the total marketing cost, respectively. The producer's net share on pooled was $91.73 \%$ in the price paid by consumer. The maximum producer's share is consumer price was $92.25 \%$ of marginal farm, followed by $90.05 \%$ on small farm and it was least $90.01 \%$ of medium farm size groups.

\subsubsection{Marketing cost}

Table 5 and figure 2 reveals that the marketing cost incurred by different intermediaries in different marketing channels, the higher marketing cost is observed in Channel II the amount being INR $189.35 \mathrm{q}^{-1}$. It is mainly because of the more number of intermediaries involved in the channel. While for channel I, where the farmer sale their produce directly to the consumer, marketing cost was INR 170.63 quintal $^{-1}$.

\subsubsection{Marketing margins of rapeseed and mustard crop}

As the market margin refers to difference between the price paid and price received by a specific marketing agency or person involved either transmission onward of commodity in term as market margin. Table 6 and Figure 3 represents the marketing margins earned by the intermediaries in the two marketing channel indentified. The retailer earned Rs. 84.98 quintal $^{-1}$ in Channel-II, where they purchase from the producer and sell it to the consumer.

\subsubsection{Price spread of Rapeseed and mustard crop}

The price which the farmer gets for his produce is known as producer's price and the price, which the consumer pay is known as consumer's price. The price includes distribution of market cost on various items of cost, the cost taken away by the middleman, traders, transporters, brokers and other functionaries. The price spread varies from place to place and commodity to commodity, similar line of finding was recommended by the Meena and Singh (2012). A study of price spread involves not only the ascertainment of the actual prices at various stages of marketing Channel, but also the cost incurred in the process of the movement of the produce from the farm to the consumer and margin of various intermediaries. Greater the number of intermediaries, higher is the value of gross margins. Higher is the value of gross margins, higher the value of price spread. And higher is the price spread; lower is the marketing efficiency as producers share in the consumer rupees become lower.

Table 7 and Figure 4 represents the price spread analysis of 


\begin{tabular}{|c|c|c|c|c|c|}
\hline \multirow[t]{2}{*}{ SI. No. } & \multirow[t]{2}{*}{ Particulars } & \multicolumn{4}{|c|}{ Farm size groups } \\
\hline & & Marginal & Small & Medium & $\begin{array}{c}\text { Pooled } \\
\text { Cost }\end{array}$ \\
\hline 1 & Producer's sale price to retailer & 3155.00 & 3130.00 & 3130.00 & 3183.34 \\
\hline 2. & Cost incurred by the producer & & & & \\
\hline i. & Packing cost & 7.00 & 8.00 & 8.00 & 7.76 \\
\hline li & Transport Cost & 100.00 & 110.00 & 110.00 & 106.67 \\
\hline lii & Market Cost & 0.00 & 0.00 & 0.00 & 0.00 \\
\hline Iv & Labour cost & 18.00 & 19.00 & 19.00 & 18.67 \\
\hline \multirow[t]{2}{*}{$\mathrm{v}$} & Miscellaneous cost & 4.00 & 5.00 & 5.00 & 4.67 \\
\hline & Total cost (i-v) & 129.00 & 142.00 & 142.00 & 137.67 \\
\hline 3. & Producer's net share & 3026.00 & 2988.00 & 2988.00 & 3045.67 \\
\hline 4. & Cost incurred by the Retailer: & & & & \\
\hline I & Labour cost & 4.00 & 4.00 & 4.00 & 4.00 \\
\hline li & Transport cost & 21.00 & 24.00 & 24.00 & 23.00 \\
\hline lii & Market cost & 2.00 & 2.00 & 2.00 & 2.00 \\
\hline IV & Packing cost & 3.00 & 4.00 & 4.00 & 3.67 \\
\hline V & Storing cost & 10.00 & 12.00 & 12.00 & 11.34 \\
\hline \multirow[t]{2}{*}{ Vi } & Miscellaneous cost & 7.00 & 8.00 & 8.00 & 7.67 \\
\hline & Total cost(i-vi) & 47.00 & 54.00 & 54.00 & 51.68 \\
\hline 5. & Retailers Net Margin & 78.00 & 116.00 & 196.00 & 84.98 \\
\hline 6. & Retailer's selling Price to Consumer's & 3280.00 & 3300.00 & 3380.00 & 3320.00 \\
\hline
\end{tabular}

Table 5: Marketing cost of intermediaries during the transaction of commodity (Rs/q)

\begin{tabular}{llcc}
\hline Sl. No. & Intermediaries & \multicolumn{2}{c}{ Marketing cost incurred } \\
\hline & & Channel-I & Channel-II \\
1. & Producer & 170.63 & 137.67 \\
2. & Retailers & 0 & 51.68 \\
3. & Total Marketing & 170.63 & 189.35 \\
& cost & & \\
\hline
\end{tabular}

$\square$ Channel $1 \quad \square$ Channel 2

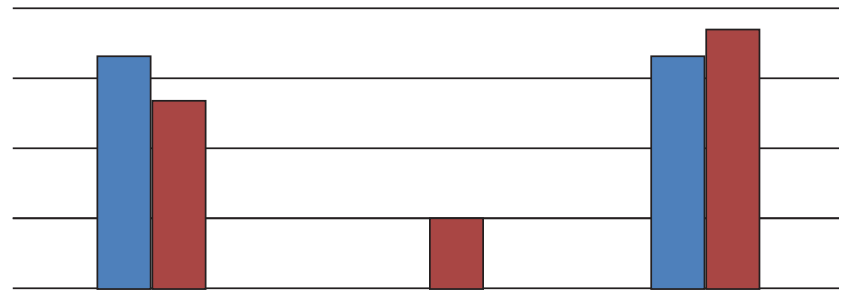

Figure 2: Marketing cost of intermediaries during the transaction of commodity $\left(₹ \mathrm{q}^{-1}\right)$

two marketing channels identified. The table shows that the producer's share in consumer's price is higher in channel I
Table 6. Marketing margin of intermediaries agencies during the marketing of rapeseed and mustard marketing on different channels $\left(₹ q^{-1}\right)$

\begin{tabular}{llcc}
\hline S I. & Intermediaries & \multicolumn{2}{c}{ Marketing cost } \\
\cline { 3 - 4 } No. & & Channel-I & Channel-II \\
\hline 1. & Producer & 170.63 & 137.67 \\
2. & Retailers & 0.00 & 51.68 \\
3. & Total Marketing Margins & 0.00 & 84.98 \\
\hline \multicolumn{4}{c}{$\square$ Channel 1 } \\
\hline
\end{tabular}

Figure 3: Marketing margin of intermediaries agencies on different channels $\left(₹ \mathrm{q}^{-1}\right)$

$(94.33 \%)$, where no intermediaries are involved. This indicates that, out of the total money paid by the consumers, the 
Table 7: Price spread analysis on different marketing channels

\begin{tabular}{llcc}
\hline SI. No. & Items & Channel-I & Channel-II \\
1. & Consumer's Price $\left(₹ \mathrm{q}^{-1}\right)$ & 3012.00 & 3320.00 \\
2. & Total marketing cost $\left(₹ \mathrm{q}^{-1}\right)$ & 170.63 & 189.35 \\
3. & $\begin{array}{l}\text { Total marketing margin } \\
\left(₹ \mathrm{q}^{-1}\right)\end{array}$ & 0.00 & 84.98 \\
& $\begin{array}{l}\text { Producer's share in con- } \\
\text { sumer price \% }\end{array}$ & 94.33 & 91.73 \\
& & \\
\hline
\end{tabular}

Channel $1 \quad \square$ Channel 2

\begin{tabular}{l|l}
\hline+1 \\
\hline \\
\hline
\end{tabular}

Figure 4: Price spread analysis on different marketing channels

producers in channel I received $94.33 \%$. The lower amount of producer's share in consumer rupee $(91.73 \%)$ is observed in channel II. While, Banafar et al. (2006) in Chhattisgarh revealed that producer share in the consumer rupee was higher in channel II (Producer- Processors of wholesale dealers of mustard oil and cake- Retailer of mustard oil and cake-consumers).

\subsection{Marketing efficiency}

In order to know the degree of the market performance, it is important to know the marketing efficiency. So, marketing efficiency can be defined as the maximization of consumer's satisfaction with the least cost incurred in providing that satisfaction through the system of marketing. It is defined as having the following two major components.

i. The effectiveness with which marketing service would be performed.

ii. The effective on the cost and the method of performing the service on production and consumption

There are the most important because the satisfaction of the consumer at the lowest possible must go hand in hand with the maintenance of a high volume of farm output. Table 8

Table 8: Estimates of marketing efficiency of different marketing channels

\begin{tabular}{llcc}
\hline Sl. No. & Items & Channel -I & Channel- II \\
\hline 1. & Consumer's price $\left(₹ \mathrm{q}^{-1}\right)$ & 3192 & 3287 \\
2 & Total marketing cost $\left(₹ \mathrm{q}^{-1}\right)$ & 170.63 & 189.35 \\
3. & Marketing efficiency & & \\
a. & Shepherds' method & 18.7071 & 17.359 \\
b. & Acharya method & 17.7171 & 11.6040 \\
\hline
\end{tabular}

reveals that the estimates of marketing efficiency of rapeseed and mustard crop or grower through various channels by using Shepherd's formula. The table shows that marketing efficiency is higher in channel- I (17.73) than in channel-II (11.14). This prove that higher is the price spread, lower is the marketing efficiency of the degree of market performance with relation to cost and method of market services has been nullified and have been proved too.

\section{Conclusion}

It may be concluded from the present study that the Channel I was more effective than channel II, due to less total marketing cost and overhead expenditure so theProducer share's in consumer rupees was less on channel I, whereas the involvement of intermediate agencies was more on channel II, therefore the marketing efficiency ofchannel I was better than the channel II either by Shepherd's methods or by Acharya's method.

\section{References}

SHR. 2015. Statistical Handbook of Rajasthan (Various issues). Published by Directorate of Economics and Statistics, Jaipur, Rajasthan.

Banafar, K. N. S., Thakur, M. K., Gauraha, A. K., 2006. Marketing of mustard in Surguja district of Chhattishgarh. Indian Journal of Agricultural Marketing 49(1), 15-19.

Choudhary, R., Rathore, D.S., Sharma, A., 2017. An Economics Analysis of Production and Marketing of Groundnut in Porbandar District of Gujarat. Economic Affairs 62(3), 547-553.

Das, K.K., Sharma, A., 2012. Growth and Variability in Area, Production and Yield of Rapeseed Mustard crop in Nagaon district of Assam. Progressive Agriculture 12(2), 392-395.

Dhakre, D.S., Sharma, A., 2010. Trends of Area, Production and Productivity of Rape-Mustard in Nagaland. Environment and Ecology 28(1 A), 270-272.

Meena, S., Singh, I. P., 2012. Price spread and efficiency of marketing of pea in Rajasthan. International Journal of Commerce and Business Management 5(2), 224-231.

Sharma, A., 2012. Growth and Variability in Area, Production and Productivity of Rapeseed Mustard in Nagaland: A Review. Agriculture Science Digest 34. September.

Sharma, A., 2013. Growth and Variability in Area, Production and Productivity of Rapeseed Mustard in Nagaland: A Review. Agriculture Science Digest 33(1), 60-62.

Sharma, A., 2018. Current Trends in Oil seed production: an Overview. International Journal of Agricultural Sciences 10(3), 5104-5114.

Yadav, M.K., Sharma, A., Rajbhar, A.K., Kalai, K., 2017. Knowledge level of farmers about the recommended package of practices and production technology on rapeseed and mustard crop: A study from Jaipur district of Rajasthan, India. Plant Archiver 17(2), 1487-1491. 